\title{
Prostate hyperplasia in St Mary's Hospital Lacor: utility of prostate specific antigen in screening for prostate malignancy
}

\author{
Ronald Okidi ${ }^{1}$, Cyprian Opira ${ }^{2}$, Vanusa Da Consolação Sambo ${ }^{1}$, Caroline Achola ${ }^{3}$. David Martin Ogwang ${ }^{1}$
}

1. St Mary's Hospital Lacor, Department of Surgery

2. St Mary's Hospital Lacor, Department of Radiology

3. St Mary's Hospital Lacor, Department of Histopathology

\begin{abstract}
Introduction: Prostate cancer is the second commonest cancer in men worldwide. At present, every patient with lower urinary tract symptoms (LUTS) in St. Mary's Hospital Lacor is undergoing prostate biopsy regardless of the prostate specific antigen (PSA) level. We sought to determine the association between PSA and malignant prostate histology.

Methods: This was a retrospective study. Data on age, PSA, prostate volume and prostate histology reported between Jan 2012 and Dec 2019 were retrieved from St. Mary's Hospital Lacor archive and analyzed using STATA SE/13.0.

Results: Records of 97 patients with LUTS was analyzed. The median (range) age of the patients was 71 (43-100) years. Median (range) of prostate volume was 91.8 (8.0-360.0) cc. Overall, PSA ranged from 0.21 to $399.2 \mathrm{ng} / \mathrm{ml}$. Prostate histology showed $3.1 \%$ acinar adenocarcinoma, $24.7 \%$ adenocarcinoma and $72.2 \%$ benign prostatic hyperplasia. The median PSA amongst patients with malignant and non-malignant prostates were $15.8 \mathrm{ng} / \mathrm{ml}$ and $6.07 \mathrm{ng} / \mathrm{ml}$ respectively. Serum PSA level was significantly higher in patients with malignant prostate histology (Difference of mean $=9.7 ; \mathrm{p}=0.001$ ).

Conclusion: Patients with LUTS and PSA levels of $15 \mathrm{ng} / \mathrm{ml}$ or more were more likely to have malignant prostate histology.

Keywords: Prostate specific antigen, Prostate cancer.

DOI: https://dx.doi.org/10.4314/ahs.v20i3.30

Cite as: Okidi R, Opira C, Sambo VD-C, Achola C, Ogwang DM. Prostate byperplasia in St Mary's Hospital Lacor: utility of prostate specific antigen in screening for prostate malignancy. Afri Health Sci. 2020;20(3): 1259-1263. bttps:/ / dx.doi.org/10.4314/ ahs.v20i3.30
\end{abstract}

\section{Background}

Globally, prostate cancer was diagnosed in $7.1 \%$ $(1,276,106)$ of the world's population and contributed to $3.8 \%(358,989)$ of all cancer deaths in 2018 and it's the second commonest cancer diagnosed in men ${ }^{1,2}$ The incidence of prostate cancer may be lower in low-middle income countries (LMIC) However, mortality has been on the rise ${ }^{3}$. In Uganda, the age-standardized mortality rate from prostate cancer has been recorded at 32.5/100,000 population ${ }^{4}$.

There are various risk factors for developing prostate cancer though age is a very strong risk factor with approxi-

\section{Corresponding author: \\ Ronald Okidi, St. Mary's Hospital Lacor P.O. Box 180, GULU (UGANDA). Tel: +256 771229853 \\ Email; ronnieokidi@gmail.com}

mately $85 \%$ of all cases diagnosed in those aged over 65 years and an estimated incidence of only $0.1 \%$ in those below the age of 50 years ${ }^{5}$. Familial predisposition to prostate cancer has been demonstrated in approximately 5-10\% of cases ${ }^{6}$.

Prostate volume has been shown to increase with age. Anatomically, a prostate volume more than $20 \mathrm{cc}$ is considered benign prostatic hyperplasia $(\mathrm{BPH})$ with obstructive symptoms appearing in prostate size more than 50 $\mathrm{cc}^{7}$.

The diagnosis of prostate cancer entails the measurement of tumour biomarkers. Currently, several assays are available to measure serum prostate specific antigen (PSA), although the exact value that is considered "abnormal" is highly controversial with historical concentration above $4.0 \mathrm{ng} / \mathrm{ml}$ considered abnormal ${ }^{8,9}$. Therefore, PSA is a sensitive serum marker for prostate cancer but its specificity is limited by a high frequency of falsely elevated values in men with $\mathrm{BPH}$, and prostatitis ${ }^{10}$.

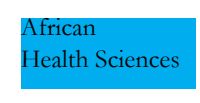

1259
(C) 2020 Okidi R et al. Licensee African Health Sciences. This is an Open Access article distributed under the terms of the Creative commons Attribution License (https://creativecommons.org/licenses/BY/4.0), which permits unrestricted use, distribution, and reproduction in any medium, provided the original work is properly cited. 
Screening for prostate cancer with PSA in the developed areas has contributed to the increasing diagnosis of prostate cancer in its early stage when confined to the prostate $^{11}$. However, $15 \%$ of men with a PSA value less than $4.0 \mathrm{ng} / \mathrm{ml}$ have prostate cancer and $15 \%$ of these cancers are of high grade ${ }^{12}$. Therefore, evaluation for prostate biopsy by using Prostate health index has shown great help in determining men who don't need prostate biopsy in comparison to other biomarkers at a sensitivity of $91 \%{ }^{13}$ as most often, prostate histology will show benign prostatic hyperplasia in $70 \%$ of sample analysed ${ }^{14}$.

Gleason grading of prostatic adenocarcinoma is one of the most powerful predictors of biological behaviour and one of the most influential factors used to determine treatment for prostate cancer ${ }^{15}$. Typical Gleason score range from 6-10, the higher the Gleason scores, the more likely that cancer will grow and spread quickly. Scores of 6 or less describe cancer cells that look similar to normal cells and suggest the cancer is likely to grow slowly, score of 7 suggests an intermediate risk for aggressive cancer and scores of 8 or higher describes cancers that are likely to spread more rapidly, these cancers are poorly differentiated $^{16}$.

Currently, a prostate biopsy is being performed on every patient with Lower urinary tract symptoms regardless of the PSA level based on previous research recommendations. This study was aimed at determining whether a high prostate specific antigen test, age, prostate volume were associated with malignant prostate and this could help to make a revised recommendation on biopsy protocol.

\section{Methods \\ Study design}

This was a retrospective review of patients' medical record of patient age, prostate volume, prostate-specific antigen, and prostate histology reports. Data collected included patient age, PSA, prostate volume, histology diagnosis and Gleason score.

Study site: St Mary's Hospital Lacor is a missionary Catholic faith-based hospital in northern Uganda, a private-not-for-profit health facility with a 483-bed capacity.

\section{Study period}

This study included data on all patients who had a prostate biopsy over the last 8 years (April 2012 - March 2019).

\section{Inclusion and exclusion criteria}

We included data of all patients who had a prostate biopsy and excluded patients' data with missing entries of prostate-specific antigen.

\section{Data collection methods}

Data were retrieved from the electronic storage computer archive of the hospital histopathology laboratory.

\section{Statistical analysis}

The analysis was performed using STATA SE/13. Data are presented in tables, independent T-test was used to determine association between age and prostate histology and Mann-Whitney U test (Wilcoxon rank sum test) to determine the association between prostate volume, prostate specific antigen and prostate histology. The level of significance was set at $\mathrm{p}=0.05$

\section{Ethical consideration}

The Lacor Hospital Institutional Research \& Ethics Committee (LHIREC) approved the study and was a review of archived data. It waived the requirement to obtain individual informed consent.

\section{Results}

A total of 97 eligible histopathological reports constituted this study. The median age of the participants was 71.0 years old, ranging between $(43.0-100.0)$ years.

The median serum PSA level was $8.8 \mathrm{ng} / \mathrm{ml}$, ranged $(0.214-399.2) \mathrm{ng} / \mathrm{ml}$. Among the PSA categories, $27.8 \%$ $(\mathrm{n}=27)$ had PSA up to $4.0 \mathrm{ng} / \mathrm{ml}, 30.9 \%(\mathrm{n}=30)$ had PSA ranged between 4 and $10 \mathrm{ng} / \mathrm{ml}$, and $41.2(\mathrm{n}=40) \% \mathrm{had}$ PSA above $10.0 \mathrm{ng} / \mathrm{ml}$. Therefore, an abnormal PSA level was found in $72.2 \%(\mathrm{n}=70)$ of the patients.

The median prostate volume was $91.8 \mathrm{cc}$, range $(8.0$ 360.0 ) cc. Enlarged prostate volume was seen in $94.9 \%$ (75/97) of the sample analysed. 
Table 1: Baseline characteristics

\begin{tabular}{|l|r|l|}
\hline Variable & $\mathbf{n}$ & $(\%)$ \\
\hline Age (years) & & \\
\hline Up to 50 & 4 & $(4.12)$ \\
\hline Above 50 & 93 & $(95.88)$ \\
\hline Prostate specific antigen & & \\
\hline $0-4 \mathrm{ng} / \mathrm{ml}$ & 27 & $(27.84)$ \\
\hline $4-10 \mathrm{ng} / \mathrm{ml}$ & 30 & $(30.93)$ \\
\hline$<10 \mathrm{ng} / \mathrm{ml}$ & 40 & $(41.24)$ \\
\hline Prostate volume & & \\
\hline$<20 \mathrm{cc}$ & 4 & $(5.06)$ \\
\hline$>20 \mathrm{cc}$ & 75 & $(94.94)$ \\
\hline Histology & & \\
\hline Prostate adenocarcinoma & 27 & $(27.84)$ \\
\hline Benign Prostatic Hyperplasia & 70 & $(72.16)$ \\
\hline Gleason score & & \\
\hline Well differentiation & 11 & $(42.31)$ \\
\hline Moderate differentiation & 12 & $(46.15)$ \\
\hline Poor differentiation & 3 & $(11.54)$ \\
\hline
\end{tabular}

Amongst the prostate biopsies, $27.87 \%$ (27/97) of the tissues were malignant and there was no malignant prostate tissue for men up to 50 years of age. Samples from men with normal PSA value, only $7.4 \%$ (2) were found to be malignant and for abnormal elevated PSA, 36.0\% (25) were malignant tissues.
Prostate histology showed 3.1\% acinar adenocarcinoma, $24.7 \%$ adenocarcinoma and $72.2 \%$ benign prostatic hyperplasia.

The Gleason score had a median of $7(6-9), 42.3 \%$ were well differentiated (Gleason 6), 46.2\% moderately differentiated (Gleason 7) and $11.5 \%$ poorly differentiated (Gleason 9)

Table 2: Comparing age, prostate volume and prostate-specific antigen with histological characteristics.

\begin{tabular}{l|lll}
\hline & $\begin{array}{l}\text { Malignant } \\
\text { prostate histology }\end{array}$ & $\begin{array}{l}\text { Non-Malignant } \\
\text { prostate histology }\end{array}$ & p-value \\
\hline \hline $\begin{array}{l}\text { Age (Completed years) } \\
\text { Median, Range }\end{array}$ & $73.0,57.0-93.0$ & $71.0 .43 .0-100.0$ & 0.140 \\
\hline $\begin{array}{l}\text { Prostate Volume (cc) } \\
\text { Median, Range }\end{array}$ & $110.0,10.0-360.0$ & $83.7,8.0-239.9$ & 0.125 \\
\hline $\begin{array}{l}\text { Prostate specific Antigen (ng/ml) } \\
\text { Median, Range }\end{array}$ & $15.8,0.21-399.2$ & $6.07,0.4-341.2$ & 0.001 \\
& & & \\
\hline
\end{tabular}




\section{Discussion}

In this 8-year retrospective study, trucut prostate histopathology reports of 97 patients were retrieved from the archive and analysed. The majority, 94.7\% (93/97) comprised of the elderly men above the age of 50 years old with a median age of 71.2 and range $(43-100)$ years. This similar age representation was also shown in previous studies indicating the occurrence of symptoms in the elderly population ${ }^{17-19}$ In this study, prostate histology showed malignancy in $27.8 \%$. Amongst the prostate adenocarcinoma observed in samples from patients with a normal PSA, $50 \%(n=1)$ has moderate differentiation which contrasted with $15 \%$ being high-grade cancers in the united states ${ }^{12}$.

In this study, malignant histology amongst the normal PSA patients was at 7.4\%. Other studies also found malignant histology in normal PSA patients as well however with a higher rate of $15.4 \%{ }^{12,17}$ As most often, prostate histology will show benign prostatic hyperplasia in 70 $\%$ of the sample analysed ${ }^{14}$, this study revealed a similar finding of histological benign prostatic hyperplasia in $72.2 \%$ of the samples and amongst the samples from patients with increased PSA, $60 \%$ of the sample had benign prostate histology signifying the low specificity of Prostate-specific antigen in cancer detention ${ }^{10}$. This exposes patients to unnecessary prostate biopsy with all its potential risks. There are studies done on use Prostate Health Index (PHI) to predict the chances of malignancy in patients with PSA between $4-10 \mathrm{ng} / \mathrm{ml}$. Thus, reducing the rates of unnecessarily performing prostate biopsy by $30 \%{ }^{20,21}$. Abnormal level of PSA was found to be asociated with malignant histology $(p=0.001)$, whereas the patient's age or prostate volume were not associated with a malignant histological $(p=0.140$ and $p=0.125$ respectively). A similar finding was also shown Irrespective of prostate size, PSA levels was found to be a strong predictor of tumour size than prostate volume ${ }^{22}$. PSA is a sensitive serum marker for prostate cancer but its specificity is limited by a high frequency of falsely elevated values in men with benign prostatic hyperplasia, and prostatitis ${ }^{10}$. However, This has contrasted with a previous study done in St Mary's Hospital Lacor who showed a non-statistical significant correlation between PSA value and prostate malignancy 17. Okuku et al (2016) found majority, 66.7\% of prostate cancer attending care at Uganda Cancer Institute had Gleason score of 9 or 10, and this study revealed the majority had a Gleason of 6 and 7. Only 11.5\% 4 had poorly differentiated adenocarcinoma with a Gleason score of 9. This contrasted greatly with the above study indicating at least a good number of prostate cancer patients are seen at an earlier stage of the disease.

\section{Conclusion}

In our setting, in one-third of men with LUTS, more than half of whom had serum PSA levels above $15.0 \mathrm{ng} / \mathrm{ml}$ had prostatic carcinoma. We demonstrated a very high association between PSA and malignant prostate histology.

\section{Acknowledgement}

Special thanks to the staff of the information technology department of St. Mary's Hospital Lacor for their assistance with data retrieval.

\section{Source of funding}

This research study was not funded.

\section{Authors contributions}

Dr Ogwang David Martin and Dr Vanusa Da Consolação Sambo contributed significantly in writing the literature, Dr Okidi Ronald contributed significantly in research writing and data analysis, Dr Opira Cyprian contributed in prostate volume measurement using ultrasound technique, and Dr Achola Caroline contributed in prostate sample histology reading.

\section{References}

1. The Union International Cancer Control. New Global Cancer Data: GLOBOCAN 2018 | UICC. Geneva, Switzerland, 12 Sept 2018 .2018;(September):1.

2. Bashir MN. Epidemiology of prostate cancer. Asian Pacific Journal of Cancer Prevention. 2015;16(13):5137-5141.

3. Brawley OW. Prostate cancer epidemiology in the United States. World Journal of Urology. 2012;30(2):195-200.

4. Gobbi H, Guerra MR, Gallo CV De, Mendonça GAES, Goldhirsch A, Wood WC, et al. Comprehensive molecular portraits of human breast tumours. Nature. 2012;7(5):57-70.

5. Patel AR, Klein EA. Risk factors for prostate cancer. Nat Clin Pract Urol. 2009;6(2):87-95.

6. Goh CL, Schumacher FR, Easton D, Muir K, Henderson B, Kote-Jarai Z, et al. Genetic variants associated with predisposition to prostate cancer and potential clinical implications. Journal of Internal Medicine. 2012;271(4):353365.

7. Berry SJ, Coffey DS, Walsh PC, Ewing LL. The devel- 
opment of human benign prostatic hyperplasia with age. J Urol. 1984;132(3):474-479.

8. Link RE, Shariat SF, Nguyen C V., Farr A, Weinberg AD, Morton RA, et al. Variation in prostate specific antigen results from 2 different assay platforms: Clinical impact on 2,304 patients undergoing prostate cancer screening. J Urol. 2004;171(6 I):2234-2238.

9. Coley CM, Barry MJ, Fleming C, Mulley AG. Early detection of prostate cancer. Part I: Prior probability and effectiveness of tests. The American College of Physicians. Ann Intern Med. 1997;126(5):394-406.

10. Sikaris K. Prostate specific antigen. Aust Prescr. 2011;34(6):186-188.

11. Barry MJ, Nelson JB. Patients present with more advanced prostate cancer since the USPSTF screening recommendations. J Urol. 2015;194(6):1534-1536.

12. Thompson IM, Ankerst DP, Chi C, Lucia MS, Goodman PJ, Crowley JJ, et al. Operating characteristics of prostate-specific antigen in men with an initial PSA level of $3.0 \mathrm{ng} / \mathrm{mL}$ or lower. J Am Med Assoc. 2005;294(1):6670.

13. Yu GP, Na R, Ye DW, Qi J, Liu F, Chen HT, et al. Performance of the Prostate Health Index in predicting prostate biopsy outcomes among men with a negative digital rectal examination and transrectal ultrasonography. Asian J Androl. 2016;18(4):633-638.

14. Rivas JG, Alvarez-Maestro M, Czarniecki M, Czarniecki S, Socarras MR, Loeb S. Negative Biopsies With Rising Prostate-Specific Antigen. What To Do? EMJ Urol. 2017;5(1):76-82.

15. Guimaraes MS, Quintal MM, Meirelles LR, Magna LA, Ferreira U, Billis A. Gleason score as predictor of clinicopathologic findings and biochemical (PSA) progression following radical prostatectomy. Int Braz J Urol. 2008;34(1):23-29.

16. Epstein JI, Egevad L, Amin MB, Delahunt B, Srigley JR, Humphrey PA. The 2014 international society of urological pathology (ISUP) consensus conference on gleason grading of prostatic carcinoma definition of grading patterns and proposal for a new grading system. Am J Surg Pathol. 2016;40(2):244-252.

17. Okello TR, Alema NO, Ogwang DM. Prostatic Specific Antigen (PSA) Relationship to Patients Age, Prostate Volume and Prostate Histology at St Mary's Hospital Lacor. East Cent African J Surg. 2014;19(2):87-96.

18. COLLINS GN, LEE RJ, McKELVIE GB, ROGERS ACN, HEHIR M. Relationship between Prostate Specific Antigen, Prostate Volume and Age in the Benign Prostate. Br J Urol. 1993;71(4):445-450.

19. Okuku F, Orem J, Holoya G, De Boer C, Thompson CL, Cooney MM. Prostate Cancer Burden at the Uganda Cancer Institute. J Glob Oncol. 2016;2(4):181-185.

20. Heijnsdijk EAM, Denham D, De Koning HJ. The Cost-Effectiveness of Prostate Cancer Detection with the Use of Prostate Health Index. Value Heal. 2016;19(2):153-157.

21. White J, Shenoy BV, Tutrone RF, Karsh LI, Saltzstein DR, Harmon WJ, et al. Clinical utility of the Prostate Health Index (phi) for biopsy decision management in a large group urology practice setting. Prostate Cancer Prostatic Dis. 2018;21(1):78-84.

22. Carvalhal GF, Daudi SN, Kan D, Mondo D, Roehl KA, Loeb S, et al. Correlation between serum prostate-specific antigen and cancer volume in prostate glands of different sizes. Urology. 2010;76(5):1072-1076. 